\title{
RALCO: ¿REPRESA O POBREZA?: LOS PROBLEMAS ÉTICOS DETRÁS DEL DESARROLLO ENERGÉTICO: EL CASO RALCO, DE DOMINGO NAMUNCURA
}

\author{
Nicolás Aldunate Villafrade
}

El libro Ralco: ¿represa o pobreza? relata lo acontecido entre los pehuenches y el megaproyecto Ralco, principalmente entre 1996 y 1998, desde la experiencia de Domingo Namuncura. La necesidad espiritual que impulsa este relato, como bien recalca el autor, es despertar nuevas conciencias para una lucha democrática contra toda forma de discriminación e injusticia social. Es decir, el libro parte de la base de que gran parte de la política energética e indígena es éticamente errónea, por lo que se hace necesario, por un lado, documentar e informar las injusticias y, por otro lado, fortalecer los derechos indígenas y sociales. De esta forma, se agradece que el autor se posicione política e ideológicamente de manera clara, sin dar pie a ambigüedades "neutrales" muy comunes entre los tecnócratas que trabajan el tema del desarrollo energético en Chile. Creer que las políticas de desarrollo energético son neutrales, objetivas y científicas, significa no comprender que estas se implementan en un contexto sociocultural, con todos los dilemas éticos que esto implica. Frente a esta visión errónea y calculada, mediante la cual la ideología imperante se disfraza de "objetiva", el relato histórico de Namuncura ofrece fuertes críticas que velan por la defensa de la cultura indígena.

Como bien menciona el autor, es necesaria una lucha democrática porque la política nacional de desarrollo energético, a lo largo de todo el país, está habituada a que el fin justifique los medios: mientras se asegure el desarrollo económico y laboral de las zonas explotadas, se puede desvalorizar y desestructurar a las culturas indígenas, entre muchos otros medios éticamente cuestionables. Mientras el desarrollo económico siga alzándose en la cúspide de nuestra jerarquía valórica, y se siga naturalizando que todo lo que se sitúa en contra o fuera de esta visión es erróneo, improductivo y sacrificable, seguirán siendo pertinentes libros como este, seguirá siendo necesaria la esperanza de que alguna vez podamos vivir de manera multicultural y ecológica.

En cuanto a su contenido, el libro cuenta con una explicación detallada de i) el proyecto de la central hidroeléctrica de Ranco, sus antecedentes previos y las negociaciones entre el Estado y ENDESA; ii) los conflictos que tuvo ENDESA en Ralco a causa de la implementación de su proyecto energético; iii) las posiciones y acciones de la CONADI, MIDEPLAN y los políticos de turno; iv) las reacciones sociales del mundo indígena; v) las ofertas legales e ilegales realizadas por ENDESA para poder implementar su proyecto; vi) las auditorias e informes jurídicos que respaldaron las permutas de tierra de las familias pehuenches; y vii) el testimonio de la prensa conservadora respecto al Caso Ralco. La minuciosa entrega de datos y el análisis del autor posibilita que el lector profundice su conocimiento de los mecanismos que permiten el usufructo empresarial de tierras indígenas ancestrales, y de las compensaciones económicas con que ENDESA buscó legitimar la desestructuración de la cultura indígena pehuenche dentro de la 
zona. Su gran aporte es que nos permite comprender los mecanismos que se usaron para la integración forzosa de los pehuenches dentro de la sociedad neoliberal, lo cual tiene como costo la aculturación y desvalorización del pueblo indígena.

De esta forma, el libro Ralco: irepresa o pobreza? cuenta con una sólida documentación política, legal e histórica que, a partir del caso particular de Ralco, relata cómo el Estado y las empresas pasan por encima del derecho indígena, albergados en una idea errada de desarrollo, protección social y cultura. En este sentido, es interesante cómo el libro desnaturaliza las nociones comunes que se tienen de estos conceptos, cuestionando qué es lo exactamente estamos entendiendo por "desarrollo" y por "protección social y cultural"; es decir, qué es lo que estamos entendiendo por ser humano y cultura.

Nunca se van a solucionar los conflictos éticos que hay detrás de las políticas de desarrollo energético, mientras no se escuchen los principios que sostienen la cosmovisión indígena y no se respete que puede haber otras formas de comprender lo que significa el ser humano y el uso de la tierra. Mediante imposiciones de desarrollo y compensaciones económicas forzadas, se está cada día más lejos de reconocer a los integrantes del pueblo indígena como sujetos con identidad y cultura valiosa, lo cual atenta contra los principios democráticos con que supuestamente nos regimos. Este libro, además de abrir camino a un diálogo positivo entre la cultura indígena y el Estado, nos deja pendiente la tarea de seguir luchando por un país más democrático y multicultural. 